\title{
Short-term starvation at low temperature prior to harvest does not impact the health and acute stress response of adult Atlantic salmon
}

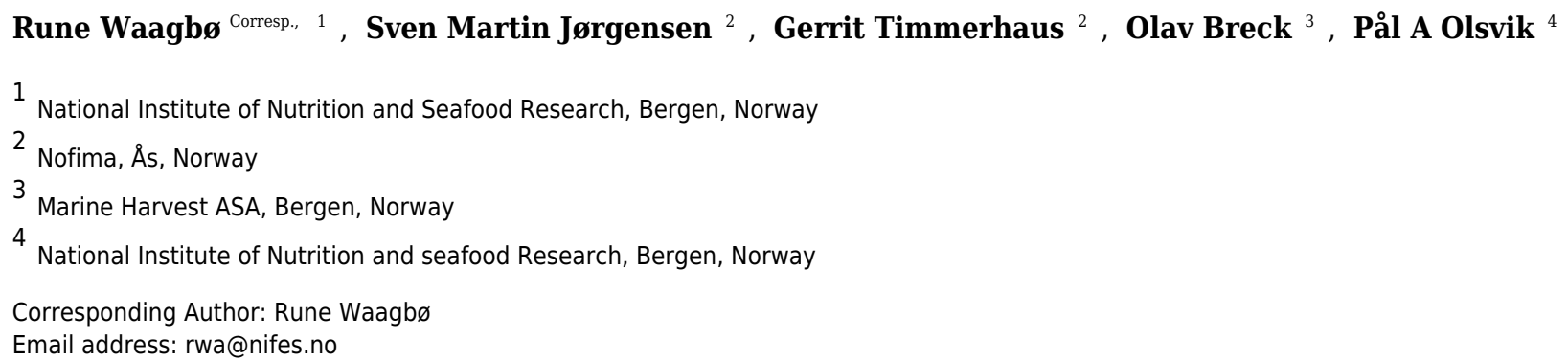

Period of starvation is regarded as a sound practice in aquaculture prior to handling, transportation and harvest, to minimise impacts on welfare and ensure proper hygiene after harvest. However, documentation of welfare issues such as stress following starvation and handling in adult Atlantic salmon are lacking. This study aimed to examine gut emptying and potential stress during a two weeks starvation period, and whether this starvation period changes the tolerance for physical stress. The study confirmed slower emptying of the gut segments at low temperature. Plasma and bile cortisol, and selected clinical analyses were used to characterize potential stress, as well as the response to acute physical crowding stress during the starvation period. Neither the general stress level nor the ability to cope with handling stress was affected by a 14 days starvation period. Down-regulation of selected nutritional related gene markers in liver indicated classical starvation responses, with reduced metabolism and oxidative pressure, and sparing of nutrients. The response to acute handling stress was not affected by two weeks of starvation. There were minor effects of starvation on stress and health markers, as evaluated by plasma lysozyme activity and gene expression of selected inflammation marker proteins in heart and skin tissues. 
1 Short-term starvation at low temperature prior to harvest does not impact the

2 health and acute stress response of adult Atlantic salmon

3 Rune Waagb $\varnothing^{1}$, Sven Martin Jørgensen ${ }^{2}$, Gerrit Timmerhaus $^{2}$, Olav Breck ${ }^{3}$, Pål A. Olsvik ${ }^{1}$

$4{ }^{1}$ National Institute of Nutrition and Seafood Research (NIFES), Bergen, Norway

$5 \quad 2$ Nofima, Ås, Norway

$6{ }^{3}$ Marine Harvest ASA, Bergen, Norway

7 Corresponding author:

8 Prof. Rune Waagbø, National Institute of Nutrition and Seafood Research (NIFES),

9 P.O. Box 2029 Nordnes, N-5817 Bergen, Norway

10 E-mail: rune.waagbo@nifes.no

11 Telephone: +4748185036 


\section{Abstract}

13 Period of starvation is regarded as a sound practice in aquaculture prior to handling, 14 transportation and harvest, to minimise impacts on welfare and ensure proper hygiene after 15 harvest. However, documentation of welfare issues such as stress following starvation and 16 handling in adult Atlantic salmon are lacking. This study aimed to examine gut emptying and 17 potential stress during a two weeks starvation period, and whether this starvation period changes the tolerance for physical stress. The study confirmed slower emptying of the gut 19 segments at low temperature. Plasma and bile cortisol, and selected clinical analyses were used to characterize potential stress, as well as the response to acute physical crowding stress during

21 the starvation period. Neither the general stress level nor the ability to cope with handling stress was affected by a 14 days starvation period. Down-regulation of selected nutritional related

23 gene markers in liver indicated classical starvation responses, with reduced metabolism and oxidative pressure, and sparing of nutrients. The response to acute handling stress was not

25 affected by two weeks of starvation. There were minor effects of starvation on stress and health markers, as evaluated by plasma lysozyme activity and gene expression of selected inflammation marker proteins in heart and skin tissues. 


\section{Introduction}

Fish are exposed to periods of starvation or restricted feed intakes both in wild and for practical reasons in aquaculture. In these periods, the fish covers the energy requirements on the expense of body stores of nutrients (Lie \& Huse, 1992). Along with the rapid expanding aquaculture production, increasing concerns on fish welfare and ethically acceptable production practices have called for scientific evaluation of biological and behavioural consequences of feeding and starvation practices (Lines \& Spence, 2012).

Fasting and feed withdrawal periods prior to transportation and harvest of Atlantic salmon is practiced to obtain complete gut evacuation and a clean digestive tract, to ensure good water quality (e.g. minimize excretion of ammonia) and to reduce metabolic rate, physical activity, hierarchy and stress during transportation (Robb, 2008; VKM, 2008). According to the quality regulations in the Norwegian food legislation, fish should be starved to empty the gut prior to harvest to ensure proper hygiene in further processing. Temperature is the major factor influencing gut evacuation rate (Usher et al., 1991). They showed that other factors such as feed composition and physical quality may also influence the evacuation time, while fish size seems less important. Large cages in commercial scale aquaculture may need longer periods for harvesting and thus the fish population will be starved for longer periods for practical reasons.

Transportation of live salmon is a stressful event involving handling, crowding and exposure to varying water qualities (VKM, 2008). Starvation is practiced also of welfare concerns since there is a general understanding that starved fish is calmer and more tolerant to stress. However, the scientific rationale for this is not substantial and primarily related to reduced metabolic rate being indicative of higher stress tolerance (Petri, 2003). Fed fish may be less robust and more susceptible to stressors (e.g. handling) based on the notion that starvation save energy for digestion and metabolic processes, the fish has lower oxygen demands, less waste production and thereby conserving easily available energy for stress coping. There are few studies demonstrating additional beneficial effects on stress tolerance by starving fish for longer periods than three days (Einen et al., 1998). Mørkøre et al. (2008) concluded that a starvation period of 
55 five weeks can apparently improve the resistant to acute stress prior to slaughtering of Atlantic 56 salmon. The pre-harvest starvation period is, however debated from a welfare perspective and 57 standard practices suggest between five and a maximum of 14 days with a priority of a cleared 58 gut (Robb, 2008).

Adaptation to starvation includes metabolic adjustments, such as reduced basal metabolic rate, reduced activity in all organs related to exogenous nutrition and swimming activity (Petri, 2003). The net result is a reduced spending of stored energy, mainly from intestinal and muscular lipid stores (Lie \& Huse, 1992; Waagbø et al., 1996). This adaptation can be observed as reduced daily loss of body mass over time and this loss seems to be temperature dependent. The daily body mass loss over a period of 28 days was higher for trout and carp reared at $20{ }^{\circ} \mathrm{C}$ than $10{ }^{\circ} \mathrm{C}$ (Petri, 2003). Salem et al. (2007) reported that three weeks starvation of rainbow trout reduced liver expression of genes involved in aerobic respiration, blood functions and immune responses, associated with a decrease in tissue metabolism. Further, an overall reduction in protein synthetic capacity was observed, and impairment of mitochondrial (aerobic) ATP production, while maintaining liver glycolytic and gluconeogenic competence. In lipid metabolism, downregulated expression in pathways associated with hepatic lipid and fatty acid transport were seen, while maintaining fatty acid oxidation mechanisms. Thus, fish may maintain tighter control on the mechanisms of protein metabolism than metabolism of lipid or carbohydrate under short term starvation.

In the present study, we aimed at examining the physiological response to starvation and if two weeks of starvation affects the robustness to physical handling in adult Atlantic salmon farmed under practical large scale farming conditions at low temperature $\left(4-5^{\circ} \mathrm{C}\right)$.

\section{Materials and methods}

Fish and sampling 
79 The present starvation study was conducted with adult Atlantic salmon (Salmo salar L.) at the 80 large scale R\&D site Centre for Aquaculture Competence (CAC), located in Langavika in 81 Gardsundfjorden, Hjelmeland (Western Norway) with approval from the Norwegian authorities 82 (Directorate of Fisheries, approval \# R-HM-20). The overall experiment and sampling were controlled by veterinarian and conducted according to the Norwegian Animal Welfare Act. These studies did not require special approval from the authorities. Technical details of the site were previously described by Waagbø et al. (2013).

The study included examination of required days of starvation for a complete gut evacuation. We examined selected clinical and gene expression markers from liver, muscle, heart and skin tissues during the two weeks starvation time. The outcome was related to plasma cortisol as a traditional primary response stress marker (Wedemeyer, 1996; Iwama, 2006). At each sampling time, corresponding groups of fish were sampled either directly from the cages or following a 45 min period with practical relevant moderate confinement stress (crowding), to examine if starvation affected the short time homeostasis to stress.

A population of adult Atlantic salmon [body weight $5608 \pm 1205 \mathrm{~g}$ (SD); length $73 \pm 4 \mathrm{~cm}$ (SD) and condition factor $1.43 \pm 0.12$ (SD); n=40 at start] had been reared in one of twelve $24 \mathrm{~m} \times 24 \mathrm{~m}$ steel cages (last period $30 \mathrm{~m}$ deep) from sea transfer until harvest. At the start of the production in September 2012, the cage was stocked with 50000 S0 smolts of approx. $80 \mathrm{~g}$ body weight. Fish were fed a standard extruded diet (Skretting, Stavanger) of appropriate pellet sizes according to the increasing fish size during the 18 months production. Details on feed and biological performance are reported elsewhere (Sissener et al., 2016). The water temperature at the period of starvation averaged $4{ }^{\circ} \mathrm{C}\left(5 \mathrm{~m}\right.$ depth; range $\left.3.8-4.2{ }^{\circ} \mathrm{C}\right)$. The fish were sampled at four time points after feeding was terminated; initially (March $6^{\text {th }}$ 2014) and at days 3, 7 and 14 of starvation. At each of the sampling points, fish were either sampled immediately after careful netting (Netted) or after a 45 min crowding stress in a narrowed catching net, similar to natural handling during harvest operations (Stressed). Fifteen Netted fish were rapidly collected (3-5 fish at a time) by careful netting and immediately killed by a blow to the head, aiming at minimizing 
106

107

108

109

110

111

stress. Each fish was weighed and length measured. Blood was collected from the caudal vein and selected tissues (liver, heart and skin) dissected and conserved. For Stressed fish, 15 fish were sampled after 45 min crowding stress, killed by a blow to the head, blood was collected from the caudal vein and selected tissues (liver and heart) were sampled and conserved as for Netted fish. Both groups were examined for gut content.

At each sampling, additional 10 fish was sampled for examining of gut content, making a total of 40 fish. At additional samplings at days 1, 2, 4, 5 and 6, forty fish was only weighed, length measured and examined for gut content after removal of the intestine.

Blood was sampled on heparin vacutainers (BD Vacutainer, Boston US) and kept chilled until centrifugation to collect plasma which was immediately frozen. Heart was sampled by dissecting out a piece of the ventricle apex stored on RNAlater (Sigma-Aldrich, MO, US). Further, a piece of the liver was stored on RNAlater. A piece of skin and muscle was sampled from the NQC region (Norwegian Quality Cut - part of the salmon behind the dorsal fin, defined as reference fillet for quality measures) from the same side and stored on RNAlater.

\section{Measurement of gut content}

The intestinal duct was carefully opened from oesophagus to hind-gut. The content of stomach, pylorus, mid- and hind-gut was characterized separately, and the content was categorized as $\mathrm{N}$ (normal), F (flocculants), M (mix/intermediate between normal and flocculants) or E (empty). Flocculants were regarded as normal remnants of faeces following several days of starvation, not negatively affecting slaughter hygiene (Figure 1). The gut evacuation time was evaluated as the sampling day (0 to 7) where no gut content was observed, except remnants defined as "flocculants".

Clinical analyses in plasma and bile 
129

130

131

132

133

Plasma cortisol, glucose, lysozyme, protein and osmolarity were analysed from 15 Netted and 15 Stressed fish at day 0, 7 and 14 after starvation. Sampled bile from Netted fish only was analysed for cortisol and osmolarity at day 0 and 14 (n=12-15). Plasma and bile were analysed for cortisol using a commercially available radioimmunoassay (RIA) kit, GammaCoat ${ }^{\mathrm{TM}}$ Cortisol ${ }^{125}$ I radio immune assay kit (DiaSorin CA1529E, Saluggia, Italy). Plasma glucose, lysozyme and protein were analysed using a clinical bioanalyzer (Maxmat PL analyzer, Montpellier, France) according to standardized procedures, reagents and controls. Osmolarity was analysed in plasma and bile by measuring the freezing point with Fiske One Ten Osmometer (Fiske Associated, Norwood, MA, US).

\section{Gene expression of metabolic markers in liver}

Table 1 shows selected metabolic gene markers (PCR primers and efficiencies) for starvation and stress within energy metabolism, oxidative health and overall protein turnover in liver tissue. Expression of these genes were analysed from 15 fish from day 0 and 14 post starvation, and from Netted and Stressed groups. Total RNA from liver was extracted using the BioRobot EZ1 and RNA Tissue Mini Kit (QiagenAB, Sollentuna, Sweden). Reverse transcription was performed using Multiscribe reverse transcriptase (Applied Biosystems, Foster City, California US). Real-time PCR was performed using SYBR Green Master Mix and the LightCycler 480 Real-Time PCR System (Roche Applied Sciences, Penzberg, Germany). Mean normalized expression (MNE) of the target genes was determined using a normalization factor based upon three un-regulated reference genes (B-actin, Elongation factor 1 alpha B and ubiquitin-60S ribosomal protein L40; Table 1), as calculated by the geNorm software (Vandesompele et al., 2002).

\section{Gene expression of stress and health markers in heart and skin}

Table 1 shows the selected stress signalling, inflammation and muscle contraction gene markers (PCR primers and efficiencies) analysed in heart and skin tissues. Heart samples were analysed, with 15 fish per time point $(0,3,7,14$ days starvation) for the Netted group, and 15 fish per time point (0 and 14 starvation) for the Stressed group. Skin samples were analysed in 15 fish at start and after 3, 7 and 14 days starvation from the Netted group only. Total RNA from heart and skin 
156 tissues was extracted from frozen tissues and cDNA synthetized with SuperScript VILO kit

157 (Applied Biosystems) using standard operational procedures. The reference gene EF1A was used

158 for normalisation of gene expression in heart and skin tissues. Ct values were calculated by $2^{\text {nd }}$

159 derivative max method as part of the LightCycler software. Relative expression was calculated 160 according to the Pfaffl method (Pfaffl 2001) adjusted for PCR efficiency.

\section{Statistics}

162 The somatic data are given as mean (SD) while the other data are given as mean (SE or pooled $163 \mathrm{SE}$ ). The treatment groups were compared with two-way ANOVA (Starvation, Crowding stress 164 and their interaction term) and Tukey's post hoc test, and graphs prepared in Graphpad Prism. 165 Skin analyses in Netted fish only was analysed by one-way ANOVA. In case of unequal variances, 166 as determined by Bartlett's test, log-transformed data were used for the ANOVA (for liver 167 MnSOD, HSP70 and HMGCR; heart IERG2, JUNB, TNF1A and INOS, and skin MUC5 and MMP9 168 gene expressions). Individual correlation analysis between the parameters was done by a 169 Spearman rank order correlation test (significant at $\mathrm{p}<0.05$ ).

\section{Results}

\section{Somatic data and gut evacuation time}

Fish weight [5347 $\pm 940 \mathrm{~g}(\mathrm{SD}), \mathrm{n}=360]$, length [72.0 $\pm 3.9 \mathrm{~cm}(\mathrm{SD}), \mathrm{n}=360]$ and condition factor [1.42 \pm 0.11 (SD), $n=360]$ were similar for all sampled fish during the 14 day study, with only a marginal increase in length from $72.8 \pm 3.9$ (SD) to $74.4 \pm 3.2(\mathrm{SD}) \mathrm{cm}$ ( $\mathrm{n}=40$ fish, $\mathrm{p}<0.047$ ), comparing the start and final samplings.

Regarding gut evacuation rates at low temperatures, Figure 1 shows \% of fish ( $n=40$ per day) with gut content in four sections (stomach, pylorus, mid-gut and hind-gut) during 14 days. The sections are gradually emptied with time, with 3, 5, 6 and 7 days in stomach, pylorus, mid-gut and hind-gut, respectively. Overall, the results showed that faeces was still found in gut sections 
180

181

182

183

from fish sampled on days 5 and 6 (mix/intermediate between normal and flocculants), implying that 7 days of starvation was needed to completely empty the gut at low temperature $\left(4-5^{\circ} \mathrm{C}\right)$.

\section{Plasma clinical and bile analyses}

The plasma cortisol values (Table 2) were generally low and indicated a moderately transiently increased concentrations with starvation $(p<0.005)$ and increased levels after confinement stress $(p<0.001)$. Plasma cortisol increased temporarily from 62 to $97 \mathrm{ng} / \mathrm{mL}$ after one week starvation, and returned to $69 \mathrm{ng} / \mathrm{mL}$ after 14 days (average levels of Netted and Stressed groups).

From Table 2, plasma protein increased significantly with starvation time $(p<0.05)$, but was not affected by confinement stress. Plasma osmolarity showed no changes with starvation, while an approx. 5\% rise in concentration was observed in Stressed versus Netted fish in all samplings $(p<0.001)$. For the entire sampled material, individual plasma cortisol was significantly positively $(p<0.05)$ related to plasma protein (Spearman rank order correlation $r=0.39 ; n=45$ ) and plasma osmolarity (Spearman rank order correlation $r=0.43 ; n=45$ ). Plasma glucose declined moderately but significantly with time of starvation (from 5.3 to $4.7 \mathrm{mM} ; \mathrm{p}<0.02$ ), and increased secondary to stress (4.6 to $5.3 \mathrm{mM}$; $\mathrm{p}<0.001$ ). Plasma lysozyme activity was neither affected by starvation nor stress (Table 2). None of the clinical markers showed significant interaction terms between starvation and stress.

\section{Bile cortisol and osmolarity}

Bile cortisol and osmolarity were analysed from the Netted samplings at start and after 14 days starvation, meaning that starvation time was the only experimental variable. Despite that mean cortisol values varied considerably at both time points, with $2210 \pm 710$ (SE) vs $350 \pm 610$ (SE) $\mathrm{ng} / \mathrm{mL}$, individual bile cortisol concentration was significantly related to resting plasma cortisol (Spearman rank order correlation 0.56; $n=27$ ). Bile cortisol was also related to bile osmolarity (Spearman rank order correlation 0.76). Bile osmolarity declined significantly from $430 \pm 21$ (SE) to $323 \pm 18$ (SE) mOsmol/L during starvation. 
205

206

207

208

209

210

211

212

213

214

215

216

217

218

219

220

221

222

223

224

225

226

227

228

229

\section{Expression of metabolic gene markers in liver}

Gene expression markers of the liver were chosen to reflect changes in energy metabolism (lipid and amino acid metabolism), oxidative status and overall protein turnover (Table 1), and how the fish copes metabolically to acute stress at start and following 14 days of starvation. Significant effects were observed after two weeks starvation on all genes (Figure 2), validating the usefulness of the chosen genes in starvation with respect to oxidation (down-regulated MnSOD; $p=0.0118$ ), cellular stress (up-regulated HSP70; $p=0.0001$ ), growth and energy metabolism (down-regulated IGFBP1B; $\mathrm{p}=0.0006$ ), nutritional stress (down-regulated GRP78; $\mathrm{p}=0.0001$ ), and lipid and steroid metabolism (down-regulated HMGCR; $p=0.0001$ ). In the present study, ubiquitin (uba52) was included as reference gene, indicating that starvation or stress did not have any major impact on protein degradation.

No significant effect was seen in the present gene markers in confined fish (Stressed) versus gently Netted fish for any of the examined genes ( $p>0.05$ ), including the HMGCR gene (Figure 2). This latter gene was chosen to explore possible differences in cortisol synthesis from cholesterol.

\section{Expression of stress signalling and inflammation gene markers in heart}

Figure 3 presents expression of two early stress signalling markers (IERG2 and JUNB) in heart tissue from Netted and Stressed fish over time after starvation. Both genes show similar significant temporal changes in expression pattern during starvation $(p=0.0066$ and $p=0.0006$, respectively). In the Netted group, both expression levels declined temporarily from 0 to 7 day of starvation, and then returning to initial levels after 14 days starvation. In the Stressed group, expression levels of both genes were generally significantly higher compared with the Netted group, confirming their immediate response to crowding stress (both $p<0.0001$ ). Expression of the cytokine TNF1a, a mediator of inflammation, cell survival and differentiation, showed higher levels in Stressed versus Netted fish ( $p=0.0431$; Figure 3 ). Within the groups there were no changes in expression levels over the two weeks starvation. Expression levels of inos, a marker 
230 of cardiovascular function and inflammation, was affected by stress but not starvation (Figure 3), 231 with reduced expression observed in Netted fish ( $p=0.029)$. Expression levels of ryr1, involved in 232 muscle contractility through regulation of myofiber contraction, showed neither changes with 233 starvation nor after confinement stress (Figure 3).

\section{Expression of mucosal and epithelial integrity gene markers in skin}

Skin tissue gene expression of mucin 5 (MUC5) and matrix metalloproteinase 9 (MMP9) were assessed in Netted fish only, and showed minor non-significant declines from day 3 to 14 of starvation (Figure 4), with lowest expression levels after 14 days of starvation.

\section{Discussion}

The objectives of this study were to examine welfare aspects, including the response to acute stress, of two weeks starvation at low temperatures in adult Atlantic salmon prior to harvest. According to the quality legislation, the fish should be starved so no feed remnants are found in the stomach or intestines. The present study examined the gut evacuation time for fourteen days starvation at low temperature, and underway the fish were examined for physiological, metabolic and welfare issues, including the short-term response to confinement stress. The frame of metabolic stress by starvation and acute confinement stress was measured by plasma and bile cortisol concentrations, related plasma clinical markers, and the regulation of a number of relevant genes in liver, heart and skin tissues.

\section{Gut evacuation time}

The present study demonstrates that current common practices with 3-4 days starvation prior to harvest (Farmed fish quality, 2001; Einen et al., 1998) is not sufficient for complete removal of feed from the stomach and gut under the low temperatures conditions in adult Atlantic salmon. The results suggest that fish should be starved for at least 5-7 days at such low temperatures. This is according to Usher et al. (1991), where calculated evacuation time was found two times 
254 longer at $4{ }^{\circ} \mathrm{C}$ than at $13{ }^{\circ} \mathrm{C}$. Earlier studies have also shown that the intestinal evacuation time 255 was inversely related to size of the previous feed intake in starved juvenile salmon (Talbot et al., 256 1985). In adult commercially grown salmon like in the present study, the fish had an optimal 257 feed intake prior to starvation and the measured feed evacuation time is therefore 258 representative for present Atlantic salmon farming at cold temperature.

\section{Stress responses}

260 Plasma cortisol values were transiently and moderately increased at 7 days starvation, after which it returned to initial levels after 2 weeks in non-stressed fish, and the relative rises after 45 min confinement stress did not seem to be influenced by starvation time. While plasma cortisol is a classical primary response marker to physical stress (Wendelaar-Bonga, 1997), evidences of changes in glucocorticoids in response to fasting in fish are contradictory. Plasma cortisol levels in otherwise unstressed fish are variously reported to be unaffected, reduced or increased by fasting. Starvation implies changes in circulating hormones and expression of their receptors in target tissues, i.e. mainly affecting organs that take part in energy metabolism. Pottinger et al. (2003) found no significant changes in plasma cortisol levels at any point during long-term fasting of rainbow trout. Their results suggested that energy mobilisation during fasting may be achieved without the endocrine involvement of growth hormone, cortisol or somatolactin. Similarly, Rosten et al. (cited in VKM 2008) found that plasma cortisol recorded regularly during 15 hrs transportation was generally lower in salmon parr starved for 6 days than in fish starved for 2 days prior to transportation. Mørkøre et al. (2008) indicated improved resistance to acute stress in long-term starved fish (35 days), especially for post mortem quality aspects. The mechanisms for this was, however not clear and the response to stress was not confirmed by plasma cortisol analyses. In a marine species like gilthead seabream (Sparus auratus) exposed to 14 days starvation, however, several fold increase in plasma cortisol was observed (Polakov et al., 2006), which was attributed increased carbohydrate (gluconeogenesis) and amino acid (transamination) metabolism to support energy. Similarly, Costas et al. (2012) found elevated cortisol and amino acids in plasma of Sengalese sole (Solea senegalensis Kaup, 1858) starved for 
283 starvation, where well-conditioned adult Atlantic salmon reared at low temperatures is less

284 dependent on cortisol induced energy mobilisation.

285 The present experiment included analyses of bile cortisol. It is assumed that bile, in line with 286 hair cortisol analysis in humans (Wikenius et al., 2016), might reflect longer-term and chronic 287 stress posed by for example starvation (Pottinger, 2008). The decline in bile cortisol and osmolarity after 14 days of starvation reflected the severely reduced intestinal activity and digestion after longer food deprivation. In line with plasma cortisol, the concentration of bile cortisol decreased after 14 days starvation and there was a positive individual correlation between the two in starved non-stressed fish. However, large variation in the bile cortisol concentration reflected both inhomogeneous mucoid bile samples and the changes in composition with time of starvation with reduced bile production and volumes of bile in the gall bladder. The analysis of bile cortisol may therefore be useful to assess changes in cortisol over time, like the endocrine elevation during parr-smolt transformation in salmonids (Shrimpton et al., 1994) and in periods of chronic stress. Since the production and storage of bile varies and declines under starvation, bile cortisol may be more successfully used as an indicator for chronically stressed fish under normal feeding regimes.

Similarly to plasma and bile cortisol concentrations, the liver HMGCR gene expression, representing cholesterol and cortisol synthesis was reduced with starvation. At start of the feed deprivation, the short-term stress seemed to activate the HMGCR gene (not significant in the applied two-way ANOVA model), while it was not responsive after 2 weeks of starvation.

Plasma osmolarity and protein were chosen as markers to examine secondary stress induced physiological disturbances in the hydro mineral balance (increased osmolarity) and protein mobilization during fasting, respectively. The moderate increase in plasma protein with time seemed therefore to reflect a normal starvation metabolism, with mobilization of labile protein reserves for energy purposes. Although lower than given reference values of plasma protein in adult Atlantic salmon, the present rise was less than the seasonal variation (Sandnes et al., 1988). The use of ubiquitin as reference gene supports the fact that starvation or stress did not 
310 have any major impact on liver protein degradation. This is in contrast to $400 \mathrm{~g}$ gilthead 311 seabream, where moderate declines in plasma protein were observed in groups starved for 14 312 days, concomitantly to elevated liver transaminase activity, supporting breakdown of amino 313 acids for energy production (Polakof et al., 2006). Besides species differences, the discrepancy 314 may well be related to rearing temperature, as seen for plasma cortisol and amino acid 315 metabolism in Sengalese sole reared at cold and warm temperatures (Costas et al., 2012).

Plasma osmolarity was not affected by 14 days starvation, while it was increased after acute stress in all samplings. This is in line with observations in gilthead seabream starved for the same period (Polakof et al., 2006) and reflects the priority of homeostasis. Moderate decline in blood glucose was seen with starvation, while hyperglycemia is a classical secondary response confirming glucose mobilisation following stress and cortisol release (Pottinger, 2008). Together with rise in plasma cortisol, the secondary moderately elevated osmolarity and hyperglycemia in the confined fish, the clinical markers together demonstrated a classical mild response to stress in the present experiment. In a recent study where $2 \mathrm{~kg}$ Atlantic salmon exposed to high seawater temperature responded by reduced feed intake and anorexia, there was no impact observed on clinical parameters or liver and white muscle fatty acid composition during a period of 8 weeks (Hevrøy et al., 2010). The fish showed reduced metabolism, however without any obvious physiological challenges. This is also in line with a previous study on adult salmon during fasting (Waagbø \& Hansen, 1997). Thus, the present study was suitable to further explore the impact of pre-harvest starvation and responses to the physical acute stress on metabolic adaptations and fish health and immunity at low temperature, as examined at gene expression level in liver, heart and skin tissue.

\section{Metabolic responses}

When fish are starved, energy-saving strategies are elicited to maintain the supply of nutrients to selected tissues, especially to the brain (Soengas et al., 1996). Liver is a central organ for nutrient channelling during starvation, both through accumulated nutrients and as a metabolic centre. This is observed by changes in metabolism, both by slowing down energy spenditure and 
337 relative changes among the energy substrates at starvation. For example, enzymes involved in 338 lipid breakdown and protein degradation and turnover will generally be up-regulated during starvation, and lipid anabolic enzymes will be down-regulated (Bauer et al., 2004; Costas et al.,

340 2011; Jagoe et al., 2002; Lange et al., 2003; Polakof et al., 2006; Salem et al., 2007; Suzuki et al.,. 2002). Starvation includes liver responses on transcriptional level for genes related to oxidative stress, autophagy, energy metabolism, stress response, lipid and steroid metabolism and protein degradation (Martin et al., 2010; Antonopoulou et al., 2013; Morales et al., 2004; Salem et al., 2007). The liver expression markers analysed in the present fish material was selected to give information on how the fish prioritised energy distribution and coped metabolically following 14 days of fasting and after exposed to stress. Significant effects were observed after two weeks starvation on all genes (Fig. 2), validating the outcome with respect to redox defence (down regulated MnSOD), cellular stress (upregulated HSP70), growth and energy metabolism (down regulated IGFBP1B), nutritional stress (down regulated GRP78) and lipid and steroid metabolism (down regulated HMGCR). All the nutritional related gene markers were down-regulated, and indicated classical starvation responses like reduced metabolism, reduced oxidative pressure and sparing of nutrients, including reduced igfbp1b expression, reflecting change in catabolism. Circulating IGF-I has been regarded as an index of recent growth in fish under changing nutritional conditions (Beckman 2011). According to Shimizu et al. (2005), the binding proteins of IGF-I have important roles in regulating the metabolic actions of circulating IGF-I. In a later paper, Shimizu et al. (2006) showed that the Chinook salmon circulating IGFBP-1, increased during catabolic states such as fasting and stress. Results from a short-term starvation study (14 days) with Atlantic salmon also showed that the liver igfbp1b mRNA and protein levels of the corresponding circulating IGFBP increased during 14 days of starvation (Hevrøy et al., 2010). The discrepancy to the declined expression in present study may rely on both the initial nutritional status of the fish and ambient temperature, where the present study was conducted with preharvest salmon of good nutritionally condition at low temperature, as compared to $128 \mathrm{~g}$ postsmolt salmon and $10^{\circ} \mathrm{C}$ in the study by Hevrøy et al. (2010). The present study could not detect any weight reduction during the 14 days starvation. The maintenance of energy homeostasis during food deprivation in fish is directly related to the capacity for mobilization of energy reserves such as lipids and hepatic glycogen, at least during the initial stages of fasting, and depends on subsequent activation of hepatic gluconeogenesis and reduction in the rate of 
368 glucose utilization (Sheridan \& Mommsen, 1991; Navarro \& Gutiérrez, 1995). The high body fat 369 stores in the present pre-harvest salmon would ensure capacity to endure starvation, while 370 continuous use of labile protein reserves may impact immunity, as shown for selected functional 371 immunological systems in adult salmon under far longer starvation periods (Waagbø \& Hansen, 372 1997; Waagbø, 2006). This may ultimately end in compromised immunity, increased 373 susceptibility to diseases and mortalities in less robust fish.

374 The moderately increased hsp70 expression with 14 days fasting was observed, probably as a protective measure corresponding to general gene down regulations. HSP70 has, however been used with mixed success to reflect unfavourable farming conditions, like feed deprivation and handling stress (Zarate \& Bradley, 2003; Olsvik et al., 2011). Zarate \& Bradley (2003) examined how HSPs responded to hatchery stress in the Atlantic salmon and concluded that HSP70 is not a sensitive indicator to aquacultural disturbances like feed deprivation, anesthesia, capture stress, crowding stress, formalin, hyperoxia and hypoxia.

In accordance with Olsvik et al. (2008), most of the examined genes in liver were not significantly regulated in confined fish versus gently netted fish, except for the trend of an upregulated hmgcr gene after short-term confinement stress (45 min) at start of the starvation period (not significant in the two-way ANOVA model). This gene was chosen to examine differences in steroid and cortisol synthesis from cholesterol after stress. Although liver is not the major site for cortisol synthesis, hmgcr gene expression was modestly upregulated in line with the moderately elevated plasma cortisol. Gornati et al. (2005) showed that both the hmgcr and hsp70 genes were upregulated in the liver of fish reared at high rearing densities. HMGCR therefore seems to be a useful early marker of the integrated stress response in Atlantic salmon, reflecting changes in steroid and lipid metabolism with both starvation and shortly after confinement stress.

392 The igfbp1b (both samplings) and grp78 (start sampling) mRNA expressions indicated a trend towards increased expression after stress (not significant), as found in earlier studies (Shimizu et 
394 al., 2011). They also found that cortisol treatment induced both igfbp-1a gene expression and 395 igfbp-1a protein in the blood, confirming their role in catabolic conditions like stress. Circulating IGFBP-1 is generally inhibitory to the IGF-1 action and the expression of igfbp $1 b$ is negatively correlated to individual growth rates is salmonids (Kawaguchi et al., 2013). For the weak rise in igfbp1b in the present study, one has to bear in mind that initiation of expression and the RNA turnover may vary between the genes, and that the present short time between the stress and sampling may have excluded genes as suitable stress markers in the present study. For example, Olsvik et al. (2011) clearly suggested that hsp70 mRNA was a good indicator recorded after two days of handling stress in Atlantic salmon, while it was not affected in the present study, recorded 45 min after stress. A study by Martin et al. (2010) in salmon parr reported that 28 days of starvation and bacterial infection (furunculosis) had profound effects on the liver transcriptome, indicating that key components of the immune system were depressed during starvation. However, following infection the starved fish attempt to compensate for this immunosuppression by increasing expression of several key immune related genes to a greater extent than seen in fish fed prior to infection. The principle of being prepared for coming feeding event in periods of starvation have been seen in several fish species experiencing and successfully surviving longer periods of starvation.

Health and immunity

Mounting an immune response requires energy and an increase in metabolic activity, and the effectiveness of the response may be related to body energy reserves. Plasma lysozyme is a simple and commonly used marker of innate immune competence in fish, as response to vaccination, infection and immunosuppression (Waagbø, 2006). In the present study, plasma lysozyme activity was related to protein concentration to prevent confounding effects of changes in water balance in stressed fish. In line with other immunological markers, plasma lysozyme values in our study did not indicate any impact of long time starvation and acute stress on immunity. This confirms the stability of innate immunity during short term fasting and the lack of priority of immunity at acute stress relative to physiologically regaining homeostasis. 
421 The effect of starvation on cardiac stress and health markers was evaluated due to the 422 integrated role of the heart in maintaining physiological and metabolic homeostasis in salmon. A 423 previous study on mice showed a broad array of molecular events in response to starvation, 424 related to lipid and glucose energy metabolism, signalling, cell structure and the immune system 425 (Suzuki et al., 2002). The high on-growth of salmon during the last phase of the production cycle 426 may affect cardiac health (e.g. induced epicarditis, remnants of virus-induced myopathies) 427 possibly causing cardiorespiratory problems and risk of incidences following transport and other 428 stressful pre-harvest events. Thus, it was relevant to assess whether prolonged starvation would 429 affect myocardial function. The impact of starvation on cardiac stress was evaluated by two 430 genes, ierg2 and junb, previously identified as immediate markers of the primary stress response to diverse perturbations in salmon. The expression of ierg 2 showed a temporary decline, ending with higher than initial levels after 14 days starvation. Both genes were significantly upregulated in the Stressed versus Netted fish, confirming their response to confinement stress. The significantly reduced expression levels of both markers in Netted fish at day 7 , returning to initial levels at day 14 suggests that fish exhibited a lower stress response compared to start and after 14 days. In response to crowding stress, there were no differences in expression levels and the immediate stress response in fish between 0 and 14 days of starvation. Plasma cortisol levels showed an opposite regulation of the heart stress markers, with rise in levels after 7 days returning to initial levels after 14 days of starvation. The opposite results between stress markers and cortisol is likely reflecting different kinetics of endocrine versus transcriptional regulation , or their involvement in different arms of the stress axis (immediate versus chronic stress). In terms of interpretation, transient short-term stress is a healthy response to regain homeostasis (allostasis), but long-term stress could indicate a negative impact on the fish health. Hence, the reduced cortisol levels following 14 days starvation in addition to unchanged regulation of immediate stress-marker suggest that starvation for two weeks has no impact on the stress response, and may in fact be more adaptive and beneficial than one week of starvation at low 447 temperature. 
450 that prolonged starvation did not lead to elevated inflammatory levels in the heart. No changes

451 in the expression level of inos with time from start to day 14, further indicates that long 452 starvation is safe in this regard. One marker for myocardial function e.g. muscle contraction, the

453 ryanodine receptor (ryr1) was neither affected by prolonged starvation. This gene has also been 454 implicated in the regulation of ATP production in heart, thus steady state expression levels 455 suggested that prolonged starvation and short-term stress did not have any negative effects on 456 myocardial function.

457 The skin of fish is a dynamic tissue with cellular turnover known to be influenced by factors 458 including stress and environmental conditions (Iger et al., 1994). Maintenance of skin and 459 epidermal integrity during starvation and stress is crucial for a proper physical and chemical 460 barrier to challenging environmental conditions and salmon lice infestation (Jensen, 2015). 461 Unchanged expression of mucin 5 (muc5) and matrix metalloproteinase 9 ( $\mathrm{mmp} 9$ ) genes in 462 starved fish suggests that prolonged starvation did not have any negative effects on skin integrity 463 in the present large scale experiment. A recent study on starvation of Atlantic salmon parr in 464 freshwater showed that food deprivation for 18 days caused a rapid decrease in the densities of 465 epidermal mucous cells, particularly in the lateral region of fish (Landeira-Dabarca et al., 2013). 466 These changes may reflect reduced tissue turnover and activity during prolonged starvation. This 467 is in line with previous observations in other fish species (Caruso et al., 2010 in the eel (Anguilla 468 anguilla L.) or Somejo et al., 2004 in the Nile tilapia (Oreochromis niloticus L.). The trend towards 469 reduced levels of skin muc5 expression at days 7 and 14 could possibly imply a similar effect of 470 prolonged starvation. The same trend was observed for $\mathrm{mmp}$, a gene that is typically 471 upregulated in response to any perturbations of the skin tissue and extracellular environment.

\section{Conclusions}

473 The data from the reported study imply that at low temperature adult salmon with large 474 accumulated body reserves prior to fasting may well handle starvation periods for two weeks, 475 without any negative effects on general stress level, immunity or health, as well as on the ability 
476 to cope with acute physical stress. A mild and temporary rise in plasma cortisol after 7 days 477 starvation was observed, while no change in primary and secondary responses to stress were 478 seen after two weeks starvation. Down-regulation of all the selected nutritional related gene 479 markers in liver indicated a classical response to starvation, like reduced metabolism, reduced 480 oxidative pressure, increased cell protection and sparing of nutrients, including reduced igfbp $1 \mathrm{~b}$ 481 expression reflecting catabolism. Starvation did not affect immunity, nor heart functions or skin 482 integrity. The stress markers in heart indicated a predictable response to acute handling stress.

\section{Acknowledgements}

484 The authors want to thank the technical staffs at NIFES (Eva Mykkeltvedt, Jacob Wessels), 485 Nofima, Ås and at CAC, Hjelmeland for their technical and analytical help. 


\section{References}

487 Antonopoulou, E., Kentepozidou, E., Feidantsis, K., Roufidou, C., Despoti, S. \& Chatzifotis, S. 488 2013. Starvation and re-feeding affect Hsp expression, MAPK activation and antioxidant enzymes 489 activity of European Sea Bass (Dicentrarchus labrax). Comparative Biochemistry and Physiology 490 Part A: Molecular \& Integrative Physiology, 165, 79-88.

491 Barton, B.A., Schreck, C.B. \& Fowler, L.G. 1988. Fasting and diet content affect stress induced 492 changes in plasma glucose and cortisol in juvenile Chinook salmon. Progressive Fish-Culturist 50, 493 16-22.

494 Bauer, M., Hamm, A. C., Bonaus, M., Jacob, A., Jaeke, J., Schorle, H., Pankratz, M. J. \& 495 Katzenberger, J. D. 2004. Starvation response in mouse liver shows strong correlation with life496 span-prolonging processes. Physiological Genomics, 17, 230-244.

497 Beckman, B.R. 2011. Perspectives on concordant and discordant relations between insulin-like 498 growth factor 1 (IGF1) and growth in fishes. General and Comparative Endocrinology, 109, 325499335.

500 Caruso, G., Maricchiolo, G., Micale,, V., Genovese, L., Caruso, R. \& Denaro, M.G. 2010. 501 Physiological responses to starvation in the European eel (Anguilla anguilla): effects on 502 haematological, biochemical, non-specific immune parameters and skin structures. Fish 503 Physiology and Biochemistry, 36, 71-83.

504 Chen, Y., Azad, M.B. \& Gibson, S.B. 2009. Superoxide is the major reactive oxygen species 505 regulating autophagy. Cell Death and Differentiation, 16, 1040-1052.

506 Costas, B., Aragao, C., Ruiz-Jarabo, I., Vargas-Chacoff, L., Arjona, F.J., Dinis, M.T., Mancera, J.M. \& 507 Conceicao, L.E.C. 2011. Feed deprivation in Sengalese sole (Solea sengalensis Kaup, 1858) 508 juveniles: effects on blood plasma metabolites and free amino acid levels. Fish Physiology and 509 Biochemistry 37, 495-504.

510 Costas, B., Aragao, C., Ruiz-Jarabo, I., Vargas-Chacoff, L., Arjona, F.J., Mancera, J.M., Dinis, M.T. \& 511 Conceicao, L.E.C. 2012. Different environmental temperatures affect amino acid metabolism in 
512 the eurytherm teleost Sengalese sole (Solea sengalensis Kaup, 1858) as indicated by changes in 513 plasma metabolites. Amino Acids 43,327-335.

514 Einen, O., Waagan, B. \& Thomassen, M. S. 1998. Starvation prior to slaughter in Atlantic salmon 515 (Salmo salar) - Effects on weight loss, body shape, slaughter- and fillet- yield, proximate and 516 fatty acid composition. Aquaculture, 166, 85-104.

517 Farmed Fish Quality 2001. Rasmussen, R. S. Quality of farmed salmonids with emphasis on 518 proximate composition, yield and sensory characteristics. Aquaculture Research, 32, 767-786.

519 FSBI (Fisheries Society of the British Isles), 2002. Fish Welfare. Breifing Report 2. Granta 520 Information systems. http://www.le.ac.uk/biology/fsbi/welfare.pdf.

521 Furné, M., García-Gallego, M., Hidalgo, M.C., Morales, A.E., Domezain, A., Domezain, J. \& Sanz, 522 A. 2009. Oxidative stress parameters during starvation and refeeding periods in Adriatic sturgeon (Acipenser naccarii) and rainbow trout (Oncorhynchus mykiss). Aquaculture Nutrition, $524 \quad 15,587-595$.

525 Gornati,R., Papis, E., Rimoldi, S., Chini, V., Terova, G., Prati, M., Saroglia, M. \& Bernardini, G. 526 2005. Molecular markers for animal biotechnology: sea bass (Dicentrarchus labrax, L.) HMG-CoA reductase mRNA. Gene, 3, 344, 299-305.

528 Hevrøy, E., Azpeleta, C., Shimizu, M., Lanzén, A., Kaiya, H., Espe, M. \& Olsvik, P. A. 2010. Effects of 529 short-term starvation on ghrelin, GH-IGF system, and IGF-binding proteins in Atlantic salmon. 530 Fish Physiology and Biochemistry, 37, 217-232.

531 Hevrøy E.M., Hunskår C., de Gelder S., Shimizu M., Waagbø R., Breck O., Takle H., Sussort S. \& 532 Hansen T. 2013. GH-IGF system regulation of attenuated muscle growth and lipolysis in Atlantic 533 salmon reared at elevated sea temperatures. Journal of Comparative Physiology B 183, 243-259.

534 Hevrøy, E.M., Tipsmark, C.K, Remø, S.C., Hansen, T., Fukuda, M., Torgersen, T., Vikeså, V., Olsvik, 535 P.A., Waagbø, R., Shimizu, M. 2015. Role of the GH-IGF-1 system in Atlantic salmon and rainbow 536 trout post smolts at elevated water temperatures. Comparative Biochemistry and Physiology 537 Part A, 188, 127-138.

538 Hevrøy, EM., Waagbø, R., Breck, O., Takle, H., Jørgensen, SM., Torgersen,T., Susort , S., Tvenning, 
539 L., Hansen, T 2012. Ghrelin is involved in voluntary anorexia in Atlantic salmon raised at 540 elevated sea temperatures. General and Comparative Endocrinology 175, 118-134.

541 Hoffer, L.J. (1999) Metabolic consequences of starvation. In: Modern Nutrition in Health and 542 Disease, $9^{\text {th }}$ Ed. (Shils, M.E., Olson, J.A., Shike, M. \& Ross, A.C. eds.), pp. 645-665. Williams \& 543 Wilkins, Baltimore, USA.

544 Hoseini, S. M., Yousefi, M., Rajabiesterabadi, H. and Paktinat, M. (2014), Effect of short-term (0$54572 \mathrm{~h}$ ) fasting on serum biochemical characteristics in rainbow trout Oncorhynchus mykiss. 546 Journal of Applied Ichthyology, 30, 569-573.

547 Iger, Y., Balm, P.H.M. \& Wendelaar Bonga, S.E. 1994. Cellular responses of the skin and changes 548 in plasma cortisol levels of trout (Oncorhynchus mykiss) exposed to acidified water. Cell and 549 Tissue Research, 278, 535-542.

550 Iwama, G.K., Afonso, L.O.B. and Vijayan, M.M. 2006. Stress in fishes. In: Ewans, D.E. and Claiborne, J.B. 551 (Eds.), The Physiology of Fishes. CRC Press, Boca Raton, FL, 319-342.

552 Jagoe, R. T., Lecker, S. H., Gomes, M. \& Goldberg, A. L. 2002. Patterns of gene expression in atrophying 553 skeletal muscles: response to food deprivation. FASEB Journal, 16, 1697-1712.

554 Jensen, L.B. 2015. Nutritional and environmental impacts on skin and mucus condition in 555 Atlantic salmon (Salmo salar L.). PhD dissertation at the University of Bergen, Norway, 76pp \& 4 556 communications)

557 Jobling, M. 1994. Fish Bioenergetics, pp 309, Chapman \& Hall, London.

558 Kakizawa, S., Kaneko, T., Hasegawa, S. \& Hirano, T. 1995. Effects of feeding, fasting, background 559 adaptation, acute stress, and exhaustive exercise on the plasma somatolactin concentrations in 560 rainbow trout. General and Comparative Endocrinology, 98, 137-146.

561 Kawaguchi, K, Kaneko, N, Fukuda, M, Nakano, Y, Kimura, S, Hara, A, Shimizu, M. 2013. Responses 562 of insulin-like growth factor (IGF)-I and two IGF-binding protein-1 subtypes to fasting and re563 feeding, and their relationships with individual growth rates in yearling masu salmon 564 (Oncorhynchus masou). Comparative Biochemistry and Physiology A, Molecular Integrated 565 Physiology, 165,191-198. 
566 Kestemont, P. \& Baras, E. 2001. Environmental factors and feed intake: Mechanisms and 567 interactions. In: Food Intake in Fish (Houlihan, D., Boujard, T. \& Jobling, M., eds.), pp. 131-156. 568 Blackwell Science Ltd., Oxford, UK.

569 Landeira-Dabarca, A., Álvarez, M. and Molist, P. 2014. Food deprivation causes rapid changes in 570 the abundance and glucidic composition of the cutaneous mucous cells of Atlantic salmon 571 Salmo salar L. Journal of Fish Diseases, 37, 899-909.

572 Lange, P., Ragni, M., Silvestri, E. Moreno, M., Schiavo, L., Lombardi, A., Farina, P., Feola, A., 573 Goglia, F. \& Lanni, A. 2003. Combined cDNA array/RT-PCR analysis of gene expression profile in 574 rat gastrocnemius muscle: relation to its adaptive function in energy metabolism during fasting. 575 The FASEB Journal express article 10.1096/fj.03-0342fje.

576 Lie, $\varnothing . \&$ Huse, I. 1992. The effect of starvation on the composition of Atlantic salmon (Salmo 577 salar). Fiskeridirektoratets Skrifter, Serie Ernæring, 5(1), 11-16.

578 Lines, J.A. \& Spence, J. 2012. Safeguarding the welfare of farmed fish at harvest. Fish Physiology 579 and Biochemistry, 38, 153-162.

580 Martin, S.A.M., Douglas, A., Houlihan, D.F. \& Secombes, C.J. 2010. Starvation alters the liver 581 transcriptome of the innate immune response in Atlantic salmon (Salmo salar). BMC Genomics, 58211,418

583 Morales, A.E., Perez-Jimenez, A., Hidalgo, M.C. Abellan, E. \& Cardenete, G. 2004. Oxidative stress 584 and antioxidant defences after prolonged starvation in Dentex dentex liver. Comparative 585 Biochemistry and Physiology Part C: Toxicology \& Pharmacology, 139, 153-161.

586 Mørkøre T., Mazo T. P.I., Tahirovic V. \& Einen, O. 2008. Impact of starvation and handling stress on rigor 587 development and quality of Atlantic salmon (Salmo salar L). Aquaculture 277, 231-238.

588 Navarro, I. \& Gutiérrez, J. 1995. Chapter 17. Fasting and starvation. In: Metabolic biochemistry, 589 biochemistry and molecular biology of fishes, vol 4. (Hochachka, P.W. \& Mommsen,T.P., eds). 590 Elsevier, Amsterdam, pp 393-434.

591 Olsvik, P.A., Lie, K. \& Hevrøy, E.M. 2009. Do anesthetics and sampling strategies affect 592 transcription analysis of fish tissues? BMC Molecular Biology 8:48, 9 pp. 
593 Olsvik, P.A., Torstensen, B.E., Hemre, G.-I., Sanden, M. \& Waagbø, R. 2011. Hepatic oxidative

594 stress in Atlantic salmon (Salmo salar L.) transferred from a diet based on marine feed

595 ingredients to a diet based on vegetable plant ingredients. Aquaculture Nutrition 17, e424-e436.

596 Petri, D. 2003. Ein betrag zum hungermetabolismus von Fishen - ein Speziesvergleich. Dr. Thesis

597 at Intitut für Tierernährung, Ernährungsshäden und Diätetik der Veterinär-medizinischen,

598 Fakultät der Universität Leipzig, Germany, 109 pp.

599 Pickering A.D. \& Pottinger T.G. 1989. Stress responses and disease resistance in salmonid fish:

600 effects of chronic elevation of plasma cortisol. Fish Physiology and Biochemistry, 7, 253-258.

601 Pfaffl M.W. 2001. A new mathematical model for relative quantification in real-time RT-PCR. Nucleic Acids 602 Res 2001, 29(9), e45.

603 Polakof, S., Arjona, F.J., Sangiao-Alvarellos, S., del Rio, M.P.M., Mancera, J.M. \& Soengas, J.L. 2006. Food 604 deprivation alters osmoregulatory and metabolic responses to salinity acclimation in gilthead sea bream 605 Sparus auratus. Journal of Comparative physiology 176, 441-452.

606 Pottinger, T.G., Rand-Weaver, M. \& Sumpter, J.P. 2003. Overwinter fasting and refeeding in 607 rainbow trout: plasma growth hormone and cortisol levels in relation to energy mobilisation. 608 Comparative Biochemistry and Physiology A, 136, 403-417.

609 Pottinger, T.G. 2008. The stress response in fish - mechanisms, effects and measurements. In: 610 Fish Welfare (Ed by E.J. Branson), Blackwell Publishing Ltd, Oxford UK, 32-48.

611 Robb, D.H.F. 2008. Welfare of fish at harvest. In: Fish Welfare (Ed by E.J. Branson), Blackwell 612 Publishing Ltd, Oxford UK, 217-241.

613 Salem, M., Silverstein, J., Rexroad III, C.E. \& Yao, J. 2007. Effect of starvation on global gene 614 expression and proteolysis in rainbow trout (Oncorhynchus mykiss). BMC Genomics, 8, 328, 1-16.

615 Sissener, N., Waagbø, R., Rosenlund, G., Tvenning, L., Susort, S., Lea, T.B., Oaland, Ø., Chen, L., \& 616 Breck, O. 2016. Reduced n-3 long chain fatty acid levels in feed for Atlantic salmon (Salmo salar 617 L.) do not reduce growth, robustness or product quality through an entire full scale commercial 618 production cycle in seawater. Aquaculture (Submitted) 
619 Sheridan, M.A. \& Mommsen, T.P. 1991. Effects of nutritional state on in vivo lipid and 620 carbohydrate metabolism of coho salmon, Oncorhynchus kisutch. General and Comparative 621 Endocrinology, 81, 473-483.

622 Shimizu, M., Beckman, B.R., Hara, A. \& Dickhoff, W.W. 2006. Measurement of circulating salmon 623 IGF binding protein-1: assay development, response to feeding ration and temperature, and 624 relation to growth parameters. Journal of Endocrinology, 188, 101-110.

625 Shimizu, M., Kishimoto, K., Yamaguchi, T., Nakano, Y., Hara, A. \& Dickhoff, W.W. 2011. Circulating 626 salmon 28- and 22-kDa insulin-like growth factor binding proteins (IGFBPs) are co-orthologs of 627 IGFBP-1. General and Comparative Endocrinology, 174, 97-106.

628 Shrimpton, J.M, Bernier, N.J. \& Randall, D.J. 1994. Changes in cortisol dynamics in wild and 629 hatchery-reared juvenile coho salmon (Oncorhynchus kisutch) during smoltification. Canadian 630 Journal of Fisheries and Aquatic Sciences, 1994, 51, 2179-2187.

631 Sissener, N., Waagbø, R., Rosenlund, G., Tvenning, L., Susort, S., Lea, T.B., Oaland, Ø., Chen, L. \& 632 Breck, O. 2016. Reduced n-3 long chain fatty acid levels in feed for Atlantic salmon (Salmo salar 633 L.) do not reduce growth, robustness or product quality through an entire full scale commercial 634 production cycle in seawater. Aquaculture, 464, 236-245.

635 Skugor, S., Grisdale-Helland, B., Refstie, S., Afanasyev, S., Vielma, J. \& Krasnov, A. 2011. Gene 636 expression responses to restricted feeding and extracted soybean meal in Atlantic salmon (Salmo salar L.). Aquaculture Nutrition, 17, 505-517.

Soemngas, J.L., Strong, E.F., Fuentes, J., Veira, J.A.R. \& Andres, M.D. 1996. Food deprivation and refeeing in Atlantic salmon, Salmo salar: effects on brain and liver carbohydrate and ketone bodies metabolism. Fish Physiology and Biochemistry, 15, 491-511.

641 Somejo, M.B., Herrera, A.A., Fabillo, M.D. \& Abucay, J.S. 2004. The development of 642 integumentary and skeletal systems of starved Nile Tilapia, Oreochromis niloticus L. In: New 643 Dimensions in Farmed Tilapia: Proceedings of the Sixth International Symposium on Tilapia in 644 Aquaculture (ed. by R. Bolivar, G. Mair \& K. Fitzsimmons), pp. 733-740. American Tilapia 645 Association, Aquaculture CRSP, and Ministry of Agriculture, Philippines, Manila. 
646 Suzuki J., Shen W. J., Nelson B. D, Selwood S. P., Murphyg M., Kanefara H., Takahashi S., Oida K., 647 Miyamori I. and Kraemer F. B. 2002. Cardiac gene expression profile and lipid accumulation in 648 response to starvation. American Journal of Physiological and Endocrinological Metabolism, 46, 649 E94-E102, 2002.

650 Usher, M.L., Talbot, C. \& Eddy, F.B. 1991. Effects of transfer to seawater on growth and feeding in 651 Atlantic salmon smolts (Salmo salar L.). Aquaculture, 94, 309-326.

652 Vandesompele, J., De Preter, K., Pattyn, F., Poppe, B., Van Roy, N., De Paepe, A., Speleman, F., 653 2002. Accurate normalization of real-time quantitative RT-PCR data by geometric averaging of 654 multiple internal control genes. Genome Biology, 3, RESEARCH0034.

655 VKM (Norwegian Scientific Committee for Food Safety) 2008. Transportation of fish within a 656 closed system. Opinion of the panel on Animal Health and Welfare of the Norwegian Scientifics 657 Committee for Food Safety, Oslo, pp. 1-63.

658 Waagbø, R. 2006. Chap 13 Feeding and disease resistance in fish. In: Biology of growing animal 659 (R. Mosenthin, J. Zentek \& T, Zebrowska, Eds). Elsevier Limited, London, UK, pp. 387-415.

660 Waagbø, R. \& Hansen, T. 1997. Effekt av sult på vekst, ernæringsstatus og helse hos stor laks. 661 Havforskningsinstituttets Havbruksrapport 1997, 72-75 (In Norwegian). (Aquaculture Report, 662 Institute of Marine Research, Bergen, Norway)

663 Waagbø, R., Berntssen, M.H.G., Danielsen, T., Hellberg, H., Kleppa, A.L., Berg Lea, T., Rosenlund, 664 G., Tvenning, L., Susort, S., Vikeså, V. \& Breck, O. 2013. Feeding Atlantic salmon diets with plant 665 ingredients during the seawater phase - a full scale net production of marine protein with focus 666 on biological performance, welfare, product quality and safety. Aquaculture Nutrition, 19, 598667618.

668 Wedemeyer, G.A. 1997. Effects on rearing conditions on the health and physiology quality of fish 669 in intensive culture. In: Iwama, G.K., Pickering, A.D., Sumpter,J.P. and Schreck, C.B. (Eds.), Fish 670 Stress and Health in Aquaculture. Cambridge University Press, Cambridge, 35-71.

671 Wendelaar Bonga, S. E. 1997. The stress response in fish. Physiological Reviews, 77,591-625. 
672 Wikenius E., Moe V., Malde M.K., Smith L., Lyle R., Waagbø R., Page C.M. \& Myhre A.M. The 673 association between hair cortisol and self-reported symptoms of depression in pregnant women. 674 PlosOne 11(9):e016 1804, 1-10.

675 Zhang J., Underwood L. E., \& D'Ercole A. J. 2001. Hepatic mRNAs up-regulated by starvation: an 676 expression profile determined by suppression subtractive hybridization. The FASEB Journal 677 express article 10.1096/fj.00-0717fje.

678 Zarate, J.\& Bradley, T.M. 2003. Heat shock proteins are not sensitive indicators of hatchery stress 679 in salmon. Aquaculture, 223, 175-187. 
680 Table 1. Tissue gene markers used in the experiment, their functional role and expected

681 response, as well as their detailed characteristics.

\begin{tabular}{|c|c|c|c|}
\hline Gene & Functional role & $\begin{array}{l}\text { Expected } \\
\text { response }\end{array}$ & Accession nu \\
\hline Liver tissue & Oxidative stress, cellular stress & & \\
\hline Mn SOD & Manganese superoxide dismutase & Down regulated & DY718412 \\
\hline \multirow[t]{2}{*}{ HSP70 } & Heat shock protein 70 & Down regulated & C169R048 \\
\hline & Energy metabolism & & \\
\hline IGFBP1B & $\begin{array}{l}\text { Insulin-like growth factor binding protein } 1 \mathrm{~B} \\
\text { Stress response }\end{array}$ & Up regulated & AY662657 \\
\hline GRP78 & $78 \mathrm{kDa}$ glucose-regulated protein precursor (GRP 78) & Up regulated & AM042306 \\
\hline HMGCR & $\begin{array}{l}\text { Lipid and steroid metabolism } \\
\text { 3-hydroxy-3-methyl-glutaryl-coenzymeA reductase } \\
\text { gene }\end{array}$ & Up regulated & $\begin{array}{l}\text { Contig1955_A } \\
\mathrm{n}\end{array}$ \\
\hline ACTB & Beta-actin & Reference gene & BG933897 \\
\hline EF1AB & Elongation factor 1 alpha B & Reference gene & BG933853 \\
\hline UBA52 & ubiquitin-60S ribosomal protein L40 & Reference gene & GO050814 \\
\hline Heart and skin tissues & Stress signaling & & \\
\hline IERG2 & Immediate early response gene 2 & & NM_00114012 \\
\hline \multirow[t]{2}{*}{ JUNB } & Jun B proto-oncogene & & NM_00113990 \\
\hline & Inflammation \& muscle contraction & & \\
\hline TNF1A & Tumor necrosis factor 1 alpha & & DQ787157.1 \\
\hline INOS & Inducible nitric oxide synthase & & AF088999.1 \\
\hline \multirow[t]{2}{*}{ RYR1 } & Ryanodine receptor isoform 1 & & DW541352 \\
\hline & Mucosal \& epithelial integrity & & \\
\hline MUC5 & Mucin-5B-like & & XM_01418848 \\
\hline MMP9 & Matrix metalloproteinase-9 & & NM_00114045 \\
\hline EF1A & Elongation factor 1 alpha & Reference gene & NM_00112362 \\
\hline
\end{tabular}


682 Table 2. Plasma clinical analyses of adult Atlantic salmon during after 7 and 14 days starvation 683 (Netted), including a short-time confinement stress (Stressed) at each time point.

\begin{tabular}{|c|c|c|c|c|c|c|c|}
\hline Treatment & Day & $\begin{array}{l}\text { Cortisol } \\
\text { ng/mL }\end{array}$ & $\begin{array}{c}\text { Glucose } \\
\mathrm{mM}\end{array}$ & $\begin{array}{c}\text { Lysozyme } \\
\text { U/g }\end{array}$ & $\begin{array}{c}\text { Protein } \\
\text { g/L }\end{array}$ & $\begin{array}{c}\text { Osmolarity } \\
\text { mOsm/L }\end{array}$ & $\mathbf{n}$ \\
\hline Netted & 0 & 48 & 5.21 & 0.32 & 32.1 & 332 & 15 \\
\hline Stressed & 0 & 77 & 5.45 & 0.29 & 36.8 & 344 & 15 \\
\hline Netted & 7 & 83 & 4.35 & 0.40 & 37.4 & 325 & 15 \\
\hline Stressed & 7 & 112 & 5.44 & 0.36 & 37.9 & 342 & 15 \\
\hline Netted & 14 & 49 & 4.39 & 0.32 & 37.7 & 328 & 15 \\
\hline Stressed & 14 & 90 & 4.99 & 0.35 & 39.4 & 342 & 15 \\
\hline Pooled SEM & & 4 & 0.10 & 0.01 & 0.7 & 2 & \\
\hline \multicolumn{8}{|l|}{ Two-way ANOVA } \\
\hline Starvation & & $p<0.005$ & $p<0.018$ & ns & $p<0.035$ & ns & \\
\hline Stress & & $p<0.001$ & $p<0.001$ & ns & ns & $p<0.001$ & \\
\hline Interaction term & & ns & ns & ns & ns & ns & \\
\hline
\end{tabular}



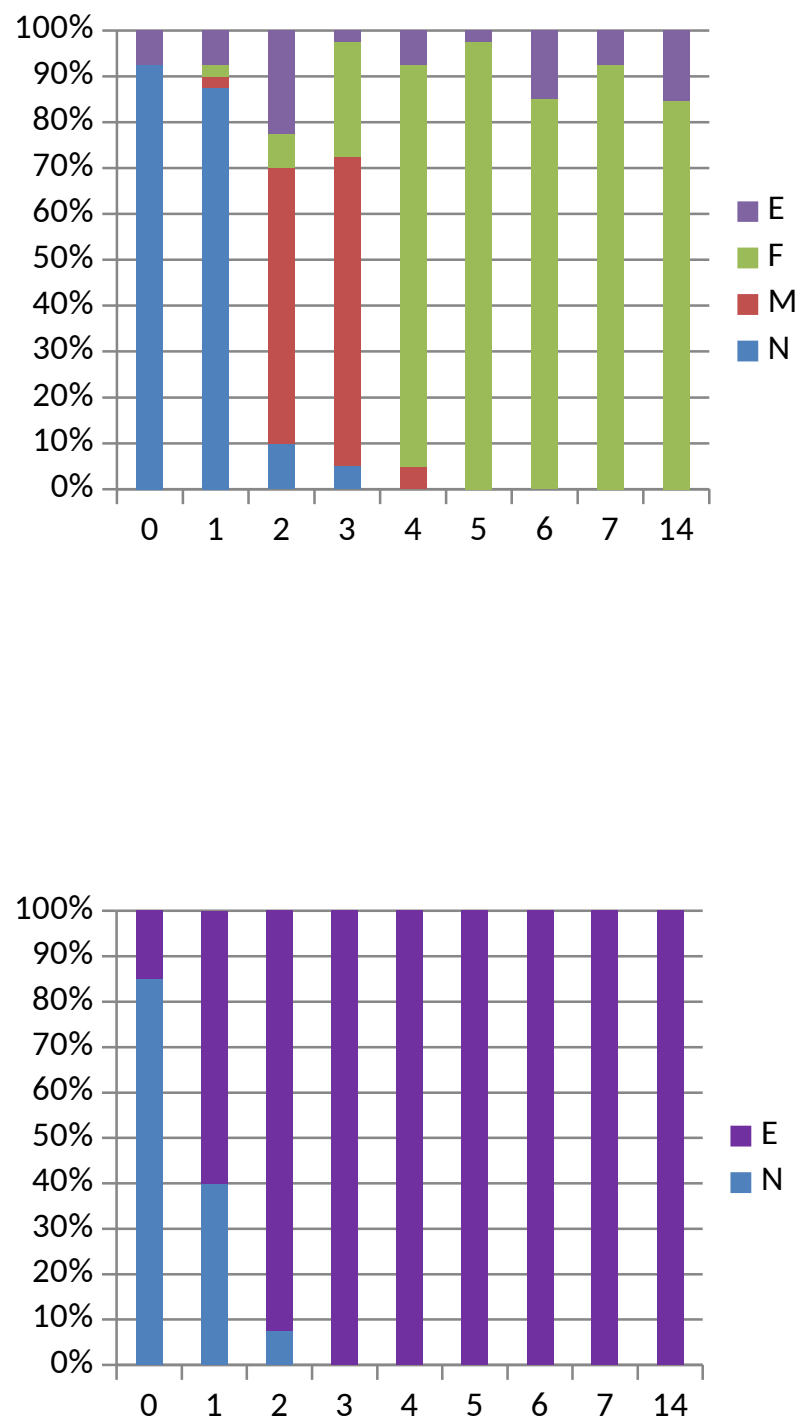

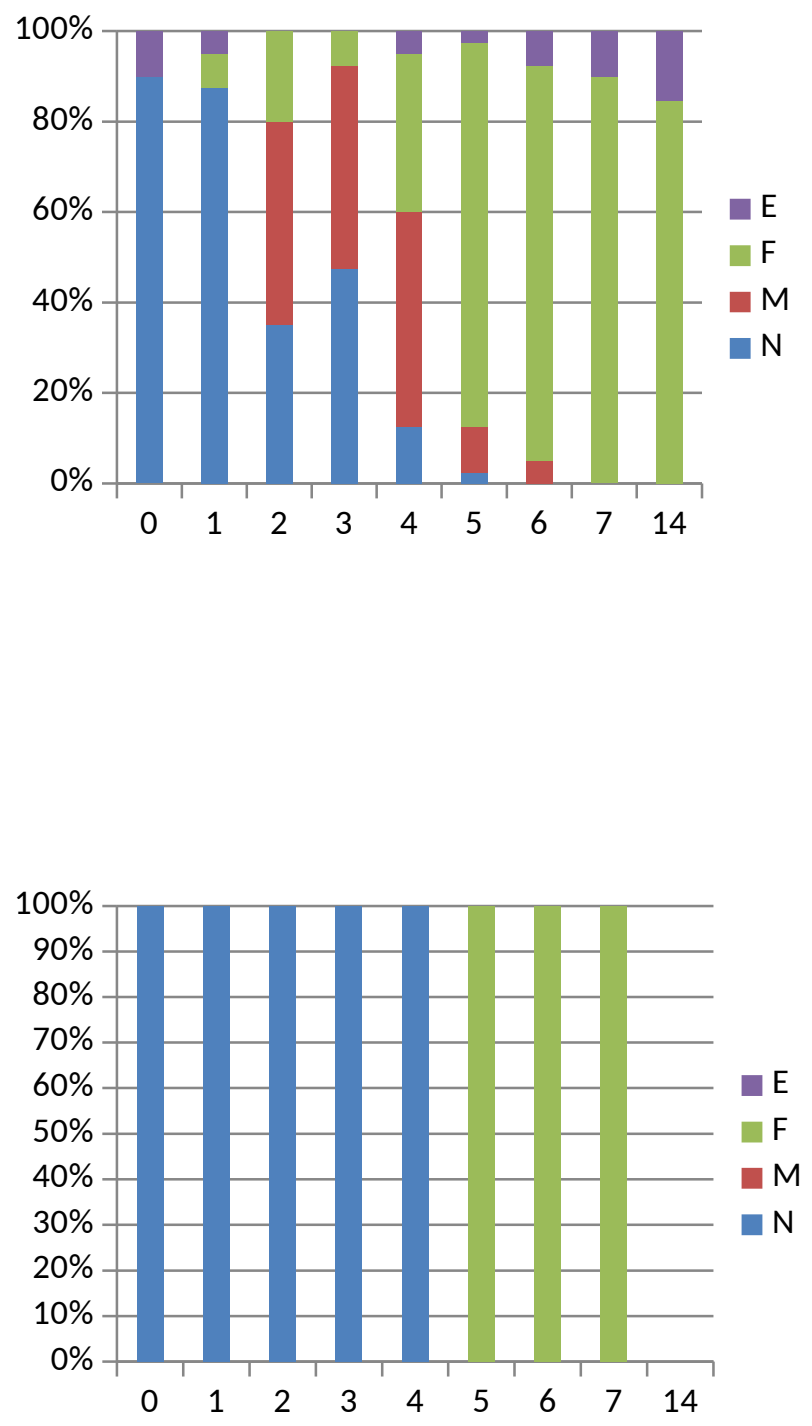

686

Figure 1. \%-Distribution of in fish per sampling day ( $n=40$ fish) with content in stomach, pylorus, mid- and hind-gut. The content was categorized as $N$ (normal), $F$ (flocculants), $M$ (mix/intermediate between normal and flocculants) or $E$ (empty). Flocculants was regarded as normal remnants of faeces following several days of starvation, not negatively affecting slaughter hygiene. The results in the graphs suggest that Atlantic salmon should be starved at least 5-7 days at low temperatures $\left(4^{\circ} \mathrm{C}\right)$ to empty the intestine. 
A

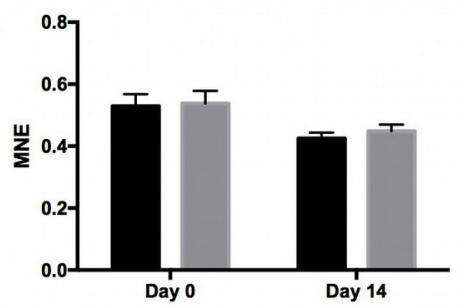

C

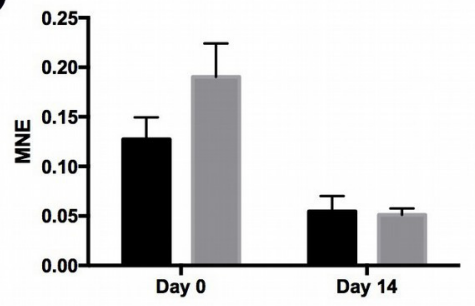

E

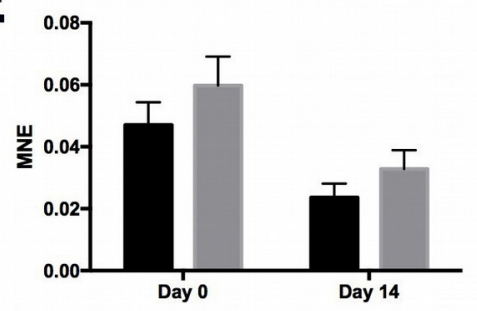

No stress

Crowding stress

2W-ANOVA

Crowding stress: $n$

Starvation: $P=0.0118$

Interaction term: ns
B

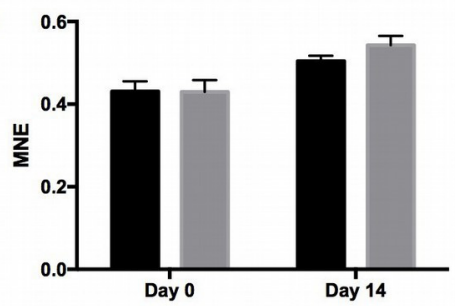

no stress

Crowding stress

2W-ANOVA

Crowding stress: $n s$

Starvation: $P<0.0001$

Interaction term: ns
D

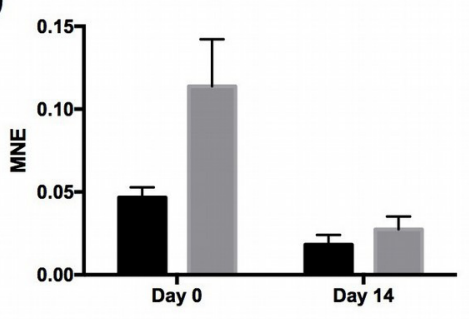

No stress

Crowding stress

2W-ANOVA

Crowding stress: ns

Starvation: $P<0.0001$

Interaction term: ns

Crowding stress: ns

Starvation: $\mathrm{P}<0.0001$

Interaction term: ns

no stress

Crowding stress

2W-ANOVA

Crowding stress: ns

Starvation: $\mathrm{P}=0.0006$

Interaction term: $\mathrm{ns}$

693 Figure 2. Gene expression of proteins in liver showed that all markers (MnSOD, HSP70, GRP78,

694 HMGCR and IGFBP1 genes) responded to starvation, and none to confinement stress (the

695 MnSOD, HSP70 and HMGCR data were log transformed). Two-way ANOVA was used to search

696 for effects of crowding and starvation between Day 0 and Day 14. Significance levels of crowding

697 stress, starvation and interaction terms are given. ns= not significant. MNE=mean normalized

698 expression. 
A

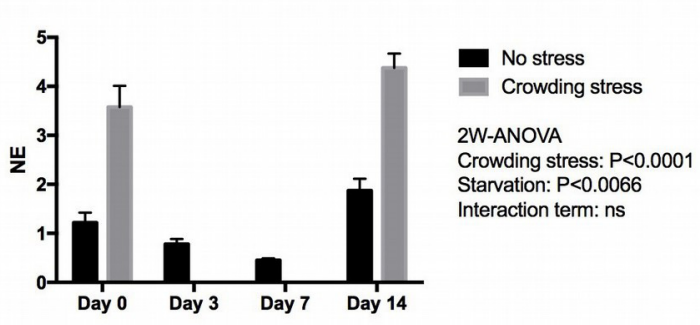

C

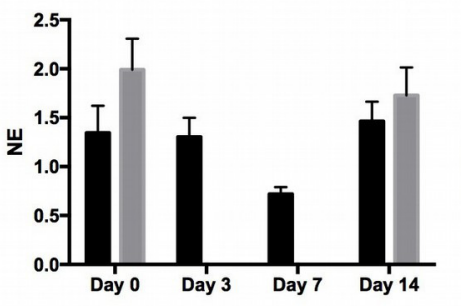

B

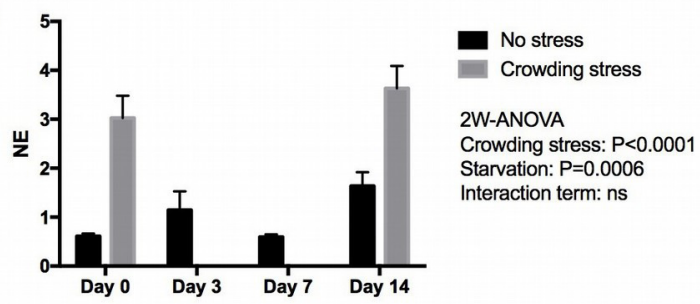

D

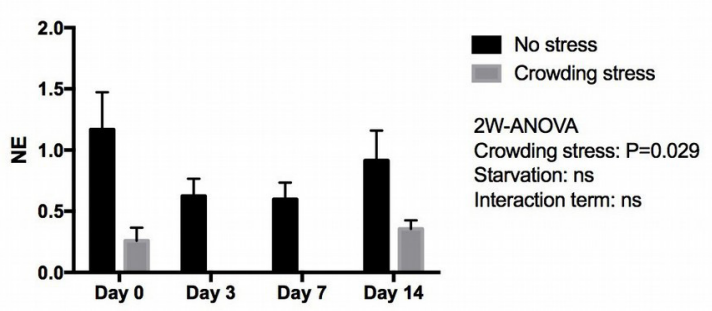

E

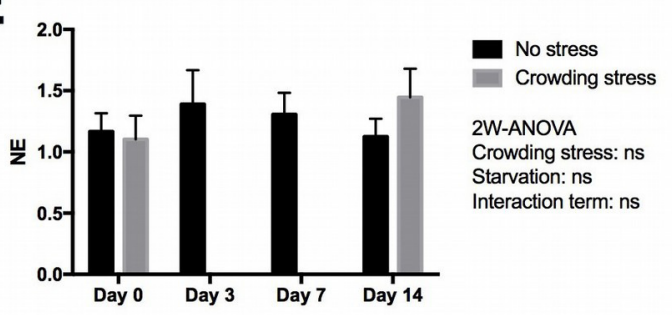

699 Figure 3. Gene expression of proteins in heart tissue showed that the selected marker IERG2 and 700 JUNB responded differently to starvation, while the IERG2, JUNB, TNF1A (log transformed) and 701 INOS (log transformed) genes responded significantly to confinement stress. Two-way ANOVA 702 was used to search for effects of crowding and starvation between Day 0 and Day 14. 703 Significance levels of crowding stress, starvation and interaction terms are given. ns= not 704 significant. $N E=$ Normalized expression. 


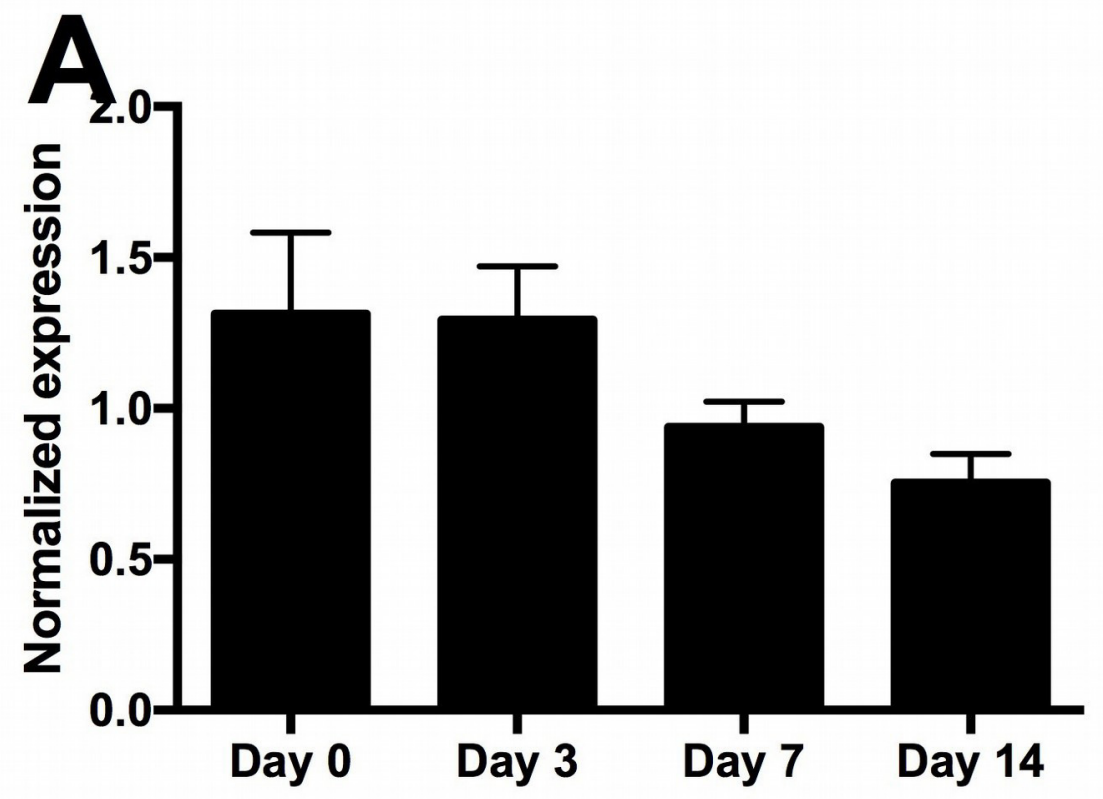

1W-ANOVA

Starvation: ns

No stress

Starvation: ns

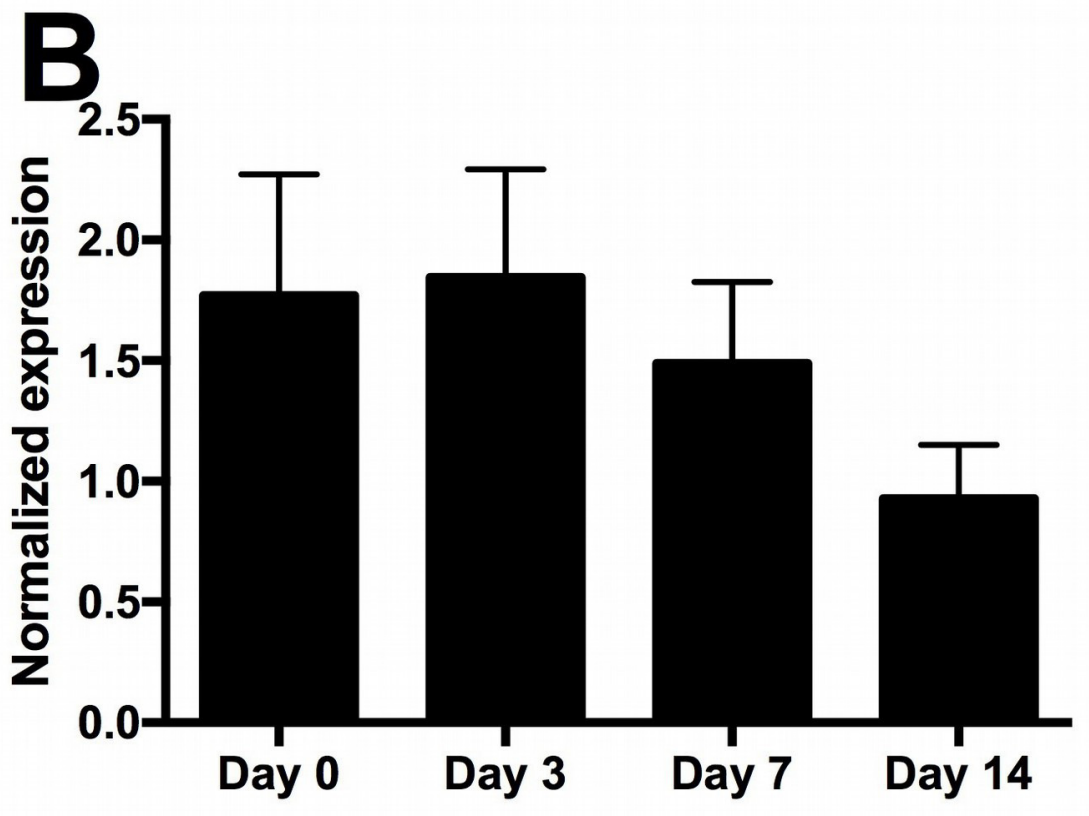

No stress

1W-ANOVA

Starvation: ns

705 Figure 4. Gene expression of proteins in skin tissue from Netted fish (No stress) showed that 706 neither MUC5 nor MMP9 genes (log transformed) responded significantly to starvation. ns=not 707 significant. 